4. Галатюк Ю. М. Концепція організації творчої навчально-пізнавальної діяльності з фізики в загальноосвітній школі / Ю. М. Галатюк // Збірник наукових праць Кам'янець-Подільського державного університету. - Кам'янець-Подільський : редакційно-видавничий відділ Кам'янець-Подільського державного університету, 2006. - Вип. 12. - С. 24-31. - (Серія «Педагогічна»).

5. Гоголева Ю. И. Педагогические условия становления методологической культуры учащихся : дис. ... кандидата пед. наук : 13.00.01 / Ю. И. Гоголева. - Псков, 2002. - 243 с.

6. Калошина И. П. Структура и механизм творческой деятельности / И. П. Калошина. - М. : Изд-во МГУ, 1983. - 168 с.

7. Лук А. Н. Психология творчества / А. Н. Лук. М. : Наука, 1978. - 126 с.
8. Лукашов В. С. Методологическая культура личности: понятие, структура, пути формирования (на материале подготовки военных инженеров) : дис. ... доктора философ. наук : 22.00 .06 / В. С. Лукашов. Санкт-Петербург, 1999. - 275 с.

9. Махмутов М. И. Организация проблемного обучения в школе. Книга для учителей / М. И. Махмутов. - М. : Просвещение, 1977. - 240 с.

10. Пономарёв Я. А. Психология творения / Я. А. Пономарёв. - Воронеж : Издательство НТО «МОДЭК», 1999. - 480 с.

11. Ухтомский А. А. Избранные труды / А. А. Ухтомский ; под ред. Е. М. Крепса. - Л. : Наука 1978. - 358 с.

12. Юдин Э. Г. Системный подход и принцип деятельности. Методологические проблемы современной науки / Э. Г. Юдин. - М. : Наука, 1978. - 392 с.

Дата надходження до редакиії: 03.10.2019 p.

Віталій ГЛАДУН,

старший викладач кафедри філософії освіти, теорії та методики суспільствознавчих предметів Миколаӥвського ОІППО

\title{
ПАРТИСИПАЦІЯ УЧНІВСЬКОЇ МОЛОДІ ЯК СКЛАДОВА ФОРМУВАННЯ ГРОМАДЯНСЬКОЇ КОМПЕТЕНТНОСТІ
}

У статті обтрунтовано процес формування громадянської компетентності учнівської молоді через партисипачію в освітньому середовищі. Розглянуто умови, щзо сприяють формуванню і розвитку особистості та ї̈ громадянського компонента.

Ключові слова: громадянська компетентність, учнівське самоврядування, учнівська молодь, демократія, партисипація.

В статье обоснован прочесс формирования гражданской компетентности учашейся молодежи через партисипацию в образовательной среде. Рассмотрены условия, что способствуют формированию и развитию личности и ее гражданского компонента.

Ключевые слова: гражданская компетентность, ученическое самоуправление, учамаяся молодежь, демократия, партисипация.

The article substantiates the process of civic competence formation of student youth through participation in the educational environment. The problem of civic competence formation among students was covered by the domestic and foreign researchers from different views. American educators have played a leading role in the study and implementation of the civic engagement among youth and they understand this process as a means of educating a law-abiding citizen of their own state and at the same time a competent, full-fledged citizen of the world. Most scholars believe that the conditions should be created in schools to involve children in the work at children and youth organizations, which contribute to the development of a person and one's civic component.

The experience of Canada and the USA is analyzed about the students active participation, when they do not stay away from the society's democratic processes, but on the contrary, while schooling they are involved in the analysis of socio-political problems through understanding of democratic values, they learn to analyze the results of government policy, to acquire the essential information to define their own position.

Particular attention should be paid to the consideration of the European Charter about the participation of young people in a public life at regional levels. Participation in a political and cultural life is one of the fundamental human rights recognized in a number of international human rights treaties, including the Universal Declaration of Human Rights. Participation is also one of the fundamental principles of the Convention on the Rights of the Child. Accordingly many human rights are difficult to access without the participation. Youth participation is not an end in itself, but a means of achieving a positive change in young people's lives and building a better society. The main ways of student youth participation are revealed and the reasons to develop the participation skills at school are identified. 
The basis for the active civic engagement of youth is a social experience, which has such components as activities and participation in a public life. Youth participation should ensure a meaningful activity, because only such activity teaches children to be tolerant citizens with democratic thinking, to take more and more responsibility for the affairs of the individual with a community, a family, and the state.

Key words: civic competence, participation, democracy, student self-government.

Постановка проблеми. Майбутне в розбудові української держави залежить від того, якими будуть iii громадяни, точніше - учнівська молодь, наскільки в них буде сформована активна життєва позиція, національна самосвідомість та ідентичність. Сьогодні надзвичайно актуальним є питання формування громадянської компетентності школярів, адже школа $\epsilon$ важливим простором для громадянської освіти, що сприяє розвитку демократичної політичної культури, формуванню громадянської компетентності, політико-правових знань, гідності та відповідальності молодих людей, усвідомленню і визнанню ними демократичних принципів життя та пріоритету прав людини.

Потрібно зрозуміти, що свідомими та активними громадянами не народжуються, ними стають у процесі навчання та виховання. Сучасне освітнє середовище вимагає докорінно нових підходів до виховання громадян не лише через знання, а й отримання певних навичок для активної громадської участі, поваги, гідності, відповідальності та співпраці з різними людьми в суспільстві.

Рівень розвитку громадянської активності зростатиме, якщо у школі громадянська діяльність буде впроваджуватися активно, а не носити суто формальний характер. Також потрібно пам'ятати, що без ефективної участі дорослих цього розвитку досягти важко.

Особливість участі дітей у житті суспільства й ухваленні рішень як соціально-педагогічного явища полягає в тому, що в центрі уваги має перебувати не вияв активності юного громадянина, а процес становлення його готовності до громадянської участі. 3 урахуванням означеного вище базовими принципами формування готовності до участі в житті суспільства й ухваленні рішень $є$ такі: принцип активності, суб'єкт-суб'єктної взаємодії, життєвої смислотворчої самодіяльності та самостійності $[11$, с. 48-49].

Аналіз наукових досліджень і публікацій. Проблему формування громадянської компетентності учнів у різноманітних аспектах висвітлювали у своïх наукових розвідках такі вітчизняні дослідники, як В. Андрющенко, I. Бех, М. Боришевський, П. Вербицька, П. Кендзьор, О. Охредько, О. Пометун, Т. Ремех, Т. Смагіна, О. Сухомлинська, К. Чорна та ін. Формування громадянської позиції молоді привертало увагу й П. Вербицької, Н. Дерев'янко, Л. Корінної, М. Рудь. У їхніх працях представлено інноваційні технології, форми і методи громадянського виховання дітей та молоді, а також обгрунтовано наукові підходи до виховання суспільно активної поведінки.

Громадянська позиція - це насамперед готовність і здатність людини до безпосередньої участі в суспільних, державних і громадських справах на основі усвідомлення своїх прав та обов'язків.

Громадянська активність, як стверджує П. Вербицька, - це спільна діяльність ініціативних громадян або груп громадян, громадських організацій, спрямована на позитивні зміни, що сприяють розвитку громади [3, с. 42].
Формування соціально-моральної орієнтації, громадянської активності та зрілості учнівської молоді через учнівське самоврядування розглядали такі педагоги, як Т. Доценко, Л. Канішевська, В. Оржеховська, М. Шимановський, С. Булавенко та ін.

Провідну роль у вивченні та впровадженні громадянської активності молоді відіграли американські педагоги, зокрема М. Йатес, Дж. Йоунісс, Р. Ніемі, Дж. Патрік, К. Фланаган, Дж. Мак Леллан, Г. Лейдвіг, Д. Кеннан, Б. Бреді та інші. Громадянськість розглядається ними як ядро національного патріотизму, засіб виховання законослухняного громадянина своєї держави та водночас компетентного, повноправного громадянина світу. Американські науковці вважають, що у школах повинні бути створені умови для залучення дітей до роботи в дитячих та юнацьких організаціях, адже це сприяє формуванню й розвитку особистості та ії громадянського компонента. У праці «Виховання громадянина: демократичні школи» педагоги зазначають, що через свою участь у системі демократичного управління школою учні не тільки пізнають, як важко самому бути демократом, але й починають розуміти, з якими труднощами сполучене демократичне управління [8, с. 4].

Мета статті - обгрунтувати процес формування громадянської компетентності учнівської молоді через партисипацію в освітньому середовищі.

Виклад основного матеріалу. Підготовка молоді до активної участі в демократичних процесах $є$ надзвичайно важливим і складним завданням. Проблема формування громадянських поглядів і переконань молоді на сучасному етапі розвитку суспільства $€$ актуальною в більшості демократичних країн світу. Так, у Канаді та США учнівська молодь не відсторонюється від демократичних процесів суспільного життя, а навпаки, вже під час навчання у школі долучається до аналізу суспільно-політичних проблем на основі розуміння демократичних цінностей, вчиться аналізувати результати діяльності уряду, оволодіває необхідною інформацією для визначення власної позиції й участі у процесі прийняття рішень у взаємодії 3 різними інститутами громадянського суспільства, а їхня життєдіяльність організовується відповідно до демократичних норм [15].

Сьогодні акцент у громадянській освіті в європейських країнах робиться на формуванні демократичної громадянськості (Education for democratic citizenship). Зокрема, у 2016 році Рада Європи ухвалила Рамку компетентностей для культури демократії, визнавши таким чином неабияку важливість розвитку громадянських компетентностей через освіту.

Європейська хартія про участь молоді в суспільному житті на місцевому та регіональному рівнях (далі - Хартія) наголошує: «Участь у житті суспільства можна вважати повноцінною лише в тому випадку, коли визнається роль молоді в політичних партіях, профспілках та громадських об'єднаннях i, що найважливіше, коли здійснюються зусилля в напрямі сприяння формуванню молодіжних об'єднань за участю та силами самих молодих людей» [9].

У преамбулі Хартії зазначається: «Участь у демократичному житті будь-якої спільноти не зводиться до голосування або висунення кандидатів на виборах; участь та активна громадянська позиція передбачають наявність прав, засобів, простору і можливостей, а де необхідно - підтримки для того, щоб брати участь i впливати на рішення, брати участь в акціях і заходах, аби сприяти побудові кращого суспільства» [9]. 
Як зауважив С. Рябов: «Демократія - це не просто правління народу, а компетентна, зацікавлена й відповідальна участь людей і громад в ухваленні суспільних рішень та розв'язанні суспільних проблем» $[12$, с. 10]. Тобто однією зі складових демократії $\epsilon$ партисипація (від англ. participate - брати участь), що являє собою свідому, активну політичну участь громадян у прийнятті важливих рішень держави. Партисипація передбачає не лише взяття участі у виборах, але й активної позиції щодо розбудови держави. Однак суспільство має створити необхідні умови для такої активної участі та соціалізації особистості. Рівного права на свободу та саморозвиток можна досягти лише в «учасницькому суспільстві» [6, с. 173].

Варто зауважити, що школа має бути також місцем, де молоді люди пізнають демократію в дії і в якому їх участь у процесі прийняття рішень знаходить підтримку, стимулюється та сприймається як ефективна.

Участь у політичному і культурному житті є одним із основних прав людини, визнаних у низці міжнародних договорів із прав людини, починаючи із Загальної декларації прав людини. Також участь - один iз основоположних принципів Конвенції про права дитини. Відповідно, без участі значна кількість прав людини є важкодоступними.

Зважаючи на означене вище, саме через участь ми можемо побудувати суспільство, що базується на правах людини, розвивати соціальну згуртованість, щоб наш голос почули ті особи, які приймають важливі рішення. Таким чином ми можемо досягти змін і в кінцевому підсумку стати суб'єктом, а не об'єктом власного життя.

Участь молоді не є самоціллю, це засіб для досягнення позитивних змін у їхньому житті та побудові кращого суспільства. Її можна також розглядати як форму партнерства між молоддю та дорослими. Водночас партнерство передбачає спільну працю, тобто необхідно прислухатися до голосу кожного й детально розглядати їх пропозиції. Саме розвиток співпраці учнівської молоді та дорослих формує соціальний капітал місцевої громади.

У науковій літературі описані моделі участі дітей і молоді у процесах прийняття рішень, зокрема «Драбина участі» Р. Харта, «Шлях до участі» Шиєра, передумови участі за моделлю Ланді.

«Драбина участі» Р. Харта - модель, що містить вісім сходинок: від «неучасті» до «участі». Вона розроблена для організацій, що готові долучати дітей $і$ молодь до проєктів. Перші три сходинки передбачають формальну участь дітей/молоді, які здійснюють мінімальний вплив. Наступні п'ять - це: призначення завдання (проєктом керують дорослі, але дітей/молодь інформують і їхня думка враховується); інформування та консультування молоді щзодо проєктів (діяльність під керівництвом дорослих з інформуванням дітей/молоді про те, яким $є$ їхній внесок і якими будуть результати участі); ініційовані дорослими прийняті спільні рішення (виникає, коли проєкт ініціюється дорослими, але його реалізація базується на спільному прийнятті рішень); проєкти ініційовані та керуються дітьми/молоддю (дорослі виконують роль помічників); проєкти керуються дітьми/молоддю, при иьому рішення ухвалюються спільно з дорослими (партнерство між дорослими і молоддю) [14].

Шиєр, базуючись на ідеях Р. Харта, свого часу виокремив п'ять категорій участі, назвавши їх «Шлях до участі»: 1) вислухати дітей; 2) підтримати їх у прагненні висловити свої погляди; 3) прийняти голос дітей всер- йоз і взяти його до уваги; 4) долучити їх до процесу прийняття рішень; 5) розділити владу й відповідальність у процесі прийняття рішень дітьми [17].

Сьогодні українське суспільство потребує активних громадян, які реалізуватимуть інтереси України в міжнародній спільноті. Старшокласники закладу освіти є резервом інтелектуальної еліти [4, с. 243].

Беручи участь у житті суспільства, учні набувають різноманітних громадянських компетентностей через досвід і дію, а саме: соціально-комунікативну компетентність, здатність критично мислити, дослідницьку компетентність, здатність розв'язувати проблеми, здатність приймати рішення, компетентність у реалізації відповідального соціального вибору, здатність до рефлексії.

Громадянська компетентність, що охоплює такі категорії, як громадянська активність, громадянська позиція, вибір та відповідальність, виявляється в соціально-комунікативних та інформаційно-дослідницьких здатностях особистості, у громадянській участі, її вміннях розв'язувати соціальні конфлікти й проблеми, ефективно діяти в ситуації невизначеності, робити відповідальний вибір й ухвалювати рішення [13, с. 39].

Як зазначає О. Тищенко, громадянське виховання дає можливість успішної соціалізації молодого покоління в сучасних умовах і саморозвитку особистості як суб'єкта діяльності. Громадянська соціалізація учнівської молоді - процес, що здійснюється не лише в спеціально організованому середовищі, а й за його межами [16, с. 173-174]. Участь школярів у суспільному житті не повинна обмежуватися рамками формальної освіти, це можуть бути й молодіжні рухи, клуби, робота волонтерських організацій і соціальних команд тощо.

Соціальним замовленням суспільства перед школою $є$ формування особистості, яка володіє не лише певним обсягом знань, умінь і навичок, а й здатна активно включатися в демократичні процеси та стати учасником самоврядування народу. Одним із важливих факторів формування в учнів таких якостей $€$ учнівське самоврядування, головною метою якого $є$ розвиток соціально активної, гуманістично спрямованої особистості з глибоко усвідомленою громадянською позицією, почуттям національної самосвідомості [10, с. 41].

Слід зауважити, що учнівська молодь іноді не зацікавлена в активній участі школи через діяльність учнівського самоврядування, тому що в освітньому процесі шкільне самоврядування носить формальний характер.

Однією із форм самоврядування $є$ учнівський менеджмент. Як стверджує С. Булавенко, учнівський менеджмент - це складна система взаємовідносин, у результаті яких розвивається здатність перетворювати неорганізований натовп в ефективну, цілеспрямовану й продуктивну групу. Сенс учнівського самоврядування в сучасному закладі загальної середньої освіти полягає не в управлінні одних дітей іншими, а в навчанні всіх учнів основам демократичних відносин у суспільстві [1].

Старшокласники прагнуть відігравати активну роль у суспільних справах, висловлювати власну думку, приймати рішення. Найефективніше залучення школярів до громадського життя відбувається через учнівське самоврядування, що зрештою перетворює старшокласників в активних суб'єктів громадянської діяльності. 
Основними причинами необхідності виховувати навички участі учнівської молоді у школі є: 1) можливість партнерства; 2) сприяння майбутньому (громадянська активність, спрямована на зміну і розвиток як громадянського суспільства, так і всього суспільства загалом); 3) розуміння відповідальності за свої дії та рішення; 4) розвиток певних навичок (лідерство, критичне мислення, аналіз, комунікабельність, кооперативність тощо); 5) формування та розвиток громадянської й соціальної компетентності; 6) активна громадянська позиція, толерантність, повага до прав і гідності людини, патріотизм та інші важливі якості, безпосередньо пов'язані з небайдужістю людини до суспільного життя, з ії зацікавленим і позитивним ставленням до різноманітності багатьох її проявів.

На думку американських дослідників, активна громадська позиція молоді може бути розвинена завдяки: а) участі учнів у дитячих та молодіжних організаціях; б) співпраці з громадою заради досягнення спільної мети через роботу в проєктах служіння громаді («community service»).

Крім того, дослідники переконані, що існує зв'язок між певними видами соціальної активності підлітків і молоді та їх ставленням до виконання громадянських обов'язків у дорослому житті [5]. Учні старших класів, які брали участь в управлінні школою та проєктах у майбутньому, стають активними громадянами держави, беруть участь у голосуванні та охочіше залучаються до громадських організацій, ніж ті, які не цікавилися життям школи та були пасивними членами шкільної громади [18, с. 623].

Організація громадянської участі учнівської молоді - це один із діяльнісних підходів громадянського виховання особистості. Громадянська участь грунтується на тому, що люди зацікавлені у процесі прийняття рішень, які стосуються їхнього життя, прагнуть бути залученими до цього процесу та активно й відповідально брати в ньому участь. Така участь може відбуватися лише на добровільній основі.

Основними видами громадянської участі учнівської молоді є:

- долучення до демократичних інституцій, що реалізується через участь у засіданнях комісій певного населеного пункту, висунення ідей та пропозицій;

- ситуативна участь, що пов'язана з конкретними, одноразовими подіями;

- участь у повсякденному житті школи;

- репрезентативні форми участі, що передбачають представлення інтересів учнів через діяльність молодіжних парламентів, учнівських рад у школах тощо;

- відкриті форми участі - систематичні збори учнів школи, мікрорайону, міста $з$ метою обговорення та прийняття рішень щодо певних питань;

- участь у соціальних проєктах [2, с. 170].

Нетрадиційними формами участі можуть бути: створення мереж «рівний - рівному»; форуми для обговорення; підпис петицій; участь у так званих нових соціальних рухах; групи підтримки; бойкотування товарів; демонстрації; міжнародні зустрічі; використання Інтернету для збору інформації, висловлення думки, впливу на прийняття рішення.

Через недостатню обізнаність молоді з проблемами місцевої громади й низький рівень мотивації щодо свідомого та активного впливу на політичне життя суспільства Україна у 2015 році долучилася до міжнародного проєкту «М18: ми можемо більше!», який передбачає розвиток громадянської активності в дітей і молоді та формування демократичної культури молодого покоління в Україні [7].

Важливою формою означеного проєкту є активний метод навчання у вигляді імітаційної гри - виборів для дітей та молоді (молодших 18 років), яка проводиться напередодні «справжніх» виборів. Ця форма призначена для відтворення певних процесів, наприклад, процесу прийняття рішення 3 метою їхнього вивчення й освоєння слухачами.

В основі гри - моделювання парламентських i президентських виборів, імітація роботи дільничної виборчої комісії та процесу голосування. Головна особливість виборів полягає в тому, що до виборчих бюлетенів заносяться списки за прихованими літерами (А, Б тощо). Для того, щоб учнівська молодь могла зробити свій вибір усвідомлено, необхідно провести низку занять із політичної просвіти для розвитку громадянської активності. Таким чином, у молоді 3'явиться стимул висловлювати свою громадянську позицію лише тоді, коли громада буде довіряти проявляти дітям та підліткам більше ініціативи та прислуховуватиметься до їхньої думки.

Щоб навчити молоде покоління бути відповідальними громадянами, які засвоїли демократичні цінності, в освітньому середовищі необхідно створити такі умови й атмосферу, які відповідали б цим цінностям. Важливо дати молоді можливість відігравати активну роль у зміцненні громадянського суспільства, вчити знаходити різноманітні способи відповідей на виклики, з якими вона стикається, приймати рішення і реалізовувати власні очікування. Саме така діяльність формує і зміцнює громадянські цінності й участь (партисипацію) молоді.

Висновки. Отже, підгрунтям для формування активної громадянської позиції молоді є соціальний досвід, складовими якого є практична діяльність та співпраця в суспільному житті. Участь молоді повинна забезпечити усвідомлену, змістовно збагачену діяльність, адже лише така активність навчає дітей бути толерантними громадянами 3 демократичним мисленням, дає змогу брати на себе все більше відповідальності за справи людини, громади, сім’ї та держави

\section{СПИСОК ВИКОРИСТАНОЇ ЛІТЕРАТУРИ}

1. Булавенко С. Д. Вплив учнівського менеджменту на формування соціальної активності особистості / С. Д. Булавенко // Наукові записки Ніжинського державного університету ім. М. Гоголя : зб. наук. пр. 2018. - № 3. - С. 11-17. - (Серія «Психолого-педагогічні науки»).

2. Вербицька П. В. Виховання громадянськості молоді через залучення до активної участі у житті місцевої спільноти / П. В. Вербицька // Вісник Львівського університету. - 2008. - С. 166-175. - (Серія «Педагогічна»).

3. Вербицька П. В. Понятійний апарат громадянського виховання особистості / П. В. Вербицька // Вісник Житомирського державного університету ім. І. Франка. - 2009. - № 43. - С. 39-44.

4. Власенко О. М. Теоретичні основи формування громадянських цінностей старшокласників в освітньому просторі навчального закладу / О. М. Власенко // Психолого-педагогічні проблеми сільської школи. - 2018. - Вип. 58. - С. 242-250. 
5. Голубкова Н. Л. Роль молодіжних організацій та рухів у становленні активної громадянської позиції американських школярів / Н. Л. Голубкова // Вісник Житомирського державного університету ім. І. Франка. - 2008. - № 42. - С. 69-73.

6. Демократія: антологія / упор. О. Проценко. - К. : Смолоскип, 2005. - 1108 с.

7. Мережа M 18: вибори для дітей і молоді. URL: https://m18.org.ua (дата звернення: 01.10.2019).

8. Мошер Р. Воспитание гражданина: демократическиешколы/ Р. Мошер, Р. Кении, Э. Гаррод;пер. с англ. ; под общ. ред. Т. Э. Балуян, Е. Я. Мигунова, Е. И. Яковлева. - М. : Народное образование, 1996. - 232 с.

9. Переглянута Свропейська хартія про участь молоді в місцевому та регіональному житті. URL: https:// rm.coe.int/168071b58f (дата звернення: 01.10.2019).

10. Петров О. В. Соціалізація школярів у процесі розвитку учнівського самоврядування / О. В. Петров, В. Ф. Петров // Таврійський вісник освіти. - 2016. № 1. - C. 41-47.

11. Петрочко Ж. В. Участь у житті суспільства як прояв соціальної ініціативності підростаючої особистості / Ж. В. Петрочко // Наукові записки Тернопільського національного педагогічного університету ім. В. Гнатюка. - 2013. - № 3. - С. 47-51. - (Серія «Педагогіка»).

12. Політична освіта в Україні: проблеми та перспективи розвитку / за заг. ред. С. Г. Рябова. - К. : Інститут громадянської освіти НаУКМА, 2005. - 44 с.
13. Ремех Т. О. Сутність і структура громадянської компетентності учня нової української школи / Т. О. Ремех // Український педагогічний журнал. 2018. - № 2. - С. 34-41.

14. Скажи своє слово : посібник із Переглянутої Європейської хартії про участь молодих людей у місцевому та регіональному житті. URL: https://rm.coe. int/have-your-say-manual-ukr/1680789a84 (дата звернення: 04.10.2019).

15. Теорія і практика виховання культури демократизму учнів старших класів загальноосвітніх навчальних закладів : автореф. дис. на здобуття наук. ступеня д-ра пед. наук : 13.00.07 / Г. А. Назаренко; Нац. акад. пед. наук України, Ін-т проблем виховання. Київ, 2016. - 44 с.

16. Тищенко О. I. Деякі умови формування громадянського виховання учнів / О. І. Тищенко // Педагогіка формування творчої особистості у вищій і загальноосвітній школах. - 2016. - Вип. 46. - С. 170-175.

17. Perry-Hazan L. The framed right to participate in municipal youth councils and its educational impact / L. Perry-Hazan, T. Nir // Children and Youth Services Review. - 2016. - № 69. - C. 174-183.

18. Youniss I. What we know about engendering civic identity / I. Youniss // American Behavioral Scientist. -1997. - Mar./Apr. - Vol. 40. - № 5. - P. 620-631.

Дата надходження до редакиії: 07.10.2019 p.
УДК 37.015.31:17.022.1 - 021.414

DOI: 10.37026/2520-6427-2019-100-4-149-153

\section{Тетяна КОВБАСЮК,}

кандидат педагогічних наук,

доиент кафедри педагогіки, психологї та

корекиійної освіти Рівненського ОІППО

\section{МОРАЛЬНІ ЦІННОСТІ СУЧАСНОГО ВИХОВАННЯ}

У статті проаналізовано моральні иінності сучасного виховання. Висвітлено основні теоретичні положення щзодо змісту і сутності прощесу виховання моральних ичінностей зростаючої особистості, зокрема на основі аналізу філософських, педагогічних та психологічних праць провідних вітчизняних науковців встановлено, щзо утвердженню моральності сприяє багаторазове здійснення самостійного морального вибору, здатність покладатися на себе $i$ відповідати за свої вчинки. Розкрито значення понять «иінності», «иіннісні орієнтаиії», «моральність», «моральні иінності». Особливу увагу акиентовано на ролі сім'ї як соиіальному інституті та важливому компоненті освітнього процесу.

Ключові слова: иінності, мораль, моральність, моральні изінності, моральна позииія, иіннісна орієнтація, структура моральних иінностей, моральна самосвідомість, виховання.
В статье проанализированы нравственнье иенности современного воспитания. Освещуены основные теоретические положения относительно содержания и сущиности проиесса воспитания нравственных иеенностей растущей личности, в частности на основе анализа философских, педагогических и психологических работ ведущих отечественньх ученьх установлено, что утверждению нравственности способствует многократное осуществление самостоятельного нравственного выбора, способность полагаться на себя и отвечать за свои поступки. Раскрыто значение понятий «ценности», «ценностные ориентации», «нравственность», «моральные иенности». Особое внимание акцентировано на роли семьи как сочиального института и важного компонента образовательного прочесса.

Ключевые слова: иенности, мораль, нравственность, моральные иенности, нравственная позиция, цеенностная ориентация, структура моральных цеенностей, моральное самосознание, воспитания. 